\title{
Validation of the Friedewald Formula in Patients with Metabolic Syndrome
}

\author{
José Knopfholz, Caio César Diniz Disserol, Andressa Jardim Pierin, \\ Fernanda Letícia Schirr, Larissa Streisky, Lilian Lumi Takito, \\ Patrícia Massucheto Ledesma, José Rocha Faria-Neto, Marcia Olandoski, \\ Claudio Leinig Pereira da Cunha, and Antonio Milton Bandeira
}

Pontifícia Universidade Católica do Paraná, Rua Imaculada Conceição, Prado Velho, 1155 Curitiba, PR, Brazil

Correspondence should be addressed to Caio César Diniz Disserol; cdisserol@gmail.com

Received 16 September 2013; Revised 13 December 2013; Accepted 26 December 2013; Published 6 February 2014

Academic Editor: Gordon Ferns

Copyright (C) 2014 José Knopfholz et al. This is an open access article distributed under the Creative Commons Attribution License, which permits unrestricted use, distribution, and reproduction in any medium, provided the original work is properly cited.

Currently, the Friedewald formula (FF) is the main method for evaluating low-density lipoprotein cholesterol (LDL-c). Recently, many limitations have emerged regarding its use, including patients with triglyceride levels $\geq 400 \mathrm{mg} / \mathrm{dL}$, diabetes mellitus, and kidney or hepatic chronic diseases. We analyzed the use of the FF in patients with metabolic syndrome. We selected patients with known metabolic syndrome that fulfilled the National Cholesterol Education Program Expert Panel on Detection, Evaluation and Treatment of High Blood Cholesterol in Adults (Adult Treatment Panel III) Final Report and excluded patients with triglyceride levels $\geq 400 \mathrm{mg} / \mathrm{dL}$ and chronic liver and/or kidney disease. Using direct assays, we measured total cholesterol, high-density lipoprotein cholesterol, triglycerides, and LDL-c. Then, LDL-c was estimated using the FF and compared with the LDL-c by direct assay. The sample size was 135 patients. Using the FF, the mean LDL-c value was $124.4 \pm 42.1 \mathrm{mg} / \mathrm{dL}$; it was $125.1 \pm 38.5 \mathrm{mg} / \mathrm{dL}$ by direct assay. The correlation coefficient between these two methods was 0.89 , with statistical significance $(P$ value $<0.001)$. There were no significant differences between the patients with triglyceride levels $>150 \mathrm{mg} / \mathrm{dL}(P=0.618)$. In conclusion, FF is a good method for estimating LDL-c in patients with metabolic syndrome.

\section{Introduction}

Metabolic syndrome (MS) comprises a group of metabolic abnormalities that are related to high cardiovascular risk, particularly for the development of coronary artery disease (CAD) [1]

MS is highly prevalent in Brazil, affecting approximately $30 \%$ of the population. The prevalence increases in older populations [2].

The main concern about MS is the development of CAD, which is a highly prevalent condition and a major cause of mortality. In the development of CAD, lipid metabolism, which is the formation of atherosclerotic plaque, plays a major role. Hypercholesterolemia is a lipid abnormality commonly related to atherosclerosis. Nevertheless, LDL-c, which is the major lipoprotein associated with CAD, is not a part of the diagnostic criteria of MS [3-5]. The physiological levels of LDL-c that are sufficient for lipid metabolism range from 25 to $60 \mathrm{mg} / \mathrm{dL}$, and LDL-c is more atherogenic when it exceeds $100 \mathrm{mg} / \mathrm{dL}$. Therefore, as previously described in the literature, lower levels of LDL-c reduce cardiovascular morbidity and mortality [6-8].

Cardiovascular risk stratification defines the LDL-c value target. Therefore, the LDL-c measurement technique requires standardization and good accuracy [6-10].

The Friedewald formula (FF) is an estimation of LDL-c level that uses the following levels of total cholesterol (TC), triglycerides (TG), and high-density lipoprotein cholesterol $(\mathrm{HDL}-\mathrm{c}): \mathrm{LDL}-\mathrm{c}(\mathrm{mg} / \mathrm{dL})=\mathrm{TC}(\mathrm{mg} / \mathrm{dL})-\mathrm{HDL}-\mathrm{c}(\mathrm{mg} / \mathrm{dL})$ - TG $(\mathrm{mg} / \mathrm{dL}) / 5[6,11-13]$. To be applied in the FF, the measurements of TC, HDL-c, and TG must be in $\mathrm{mg} / \mathrm{dL}$; the estimation differs and was not performed for the $\mathrm{mmol} / \mathrm{L}$ measurements. The FF became the standard method for LDL$\mathrm{c}$ assessment because it is economical and simpler than direct 
assays, the most accurate LDL-c measurement methods [9, 11-13].

FF has limitations under certain conditions, primarily when metabolic abnormalities alter the relationship between very-low-density lipoprotein cholesterol (VLDL-c) and TG, as in high hypertriglyceridemia (TG > $400 \mathrm{mg} / \mathrm{dL}$ ) [11, 1316]. Furthermore, new studies show considerable differences between the estimation and direct assessment of LDL-c in many other conditions $[6,7,12,13]$.

As in MS, there are changes in the disposition and metabolism of lipids; thus, the FF estimates LDL-c by assessing other lipid particles. Likely, its use in MS may not be reliable.

\section{Materials and Methods}

We selected patients with known metabolic syndrome that fulfilled the criteria outlined in the National Cholesterol Education Program Expert Panel on Detection, Evaluation and Treatment of High Blood Cholesterol in Adults (Adult Treatment Panel III) Final Report [6, 12]; three or more of the following components were present: increased waist circumference ( $\geq 102 \mathrm{~cm}$ for men and $\geq 88 \mathrm{~cm}$ for women); triglycerides $\geq 150 \mathrm{mg} / \mathrm{dL}$ or drug treatment for elevated TG; low HDL-c ( $<40 \mathrm{mg} / \mathrm{dL}$ for men and $<50 \mathrm{mg} / \mathrm{dL}$ for women) or drug treatment for low HDL-c; systolic blood pressure $\geq 130 \mathrm{mmHg}$, diastolic blood pressure $\geq 85 \mathrm{mmHg}$, or treatment with antihypertensive in patients with a history of hypertension; fasting glucose $\geq 100 \mathrm{mg} / \mathrm{dL}$ or treatment for high blood glucose.

Patients who fulfilled the MS criteria, consented to provide a blood sample, and signed the informed consent form were included in the study. Patients who did not fulfill the MS criteria, did not sign the informed consent form, and had TG $\geq 400 \mathrm{mg} / \mathrm{dL}$ were excluded.

All participants underwent a 12-hour fast. The following tests were performed (using a Selectra II analyzer with reagents and calibrators from ELITech): direct assays for TC, HDL-c, LDL-c, and TG. The results were applied in the FF, and then the LDL-c estimation could be performed. LDL-c was determined by a homogenous direct assay (i.e., colorimetry) using an ELITech kit. Colorimetry is a third generation method (a homogeneous assay with some reagents that can solubilize or specifically block these lipoproteins, dosing LDL-c alone in the same bucket with an enzymatic reaction) [17]. Thus, we could compare both LDL-c values (using the FF and by direct assay) and evaluate the reliability of the FF in the MS patients.

The results were described as means, medians, minimum values, maximum values, and standard deviations (quantitative variables) or by frequency and percentiles (qualitative variables). For the assessment of the results of LDL-c using the FF and LDL-c by direct assay was used the Student's $t$ test for paired samples. To evaluate the correlation between both methods, Pearson's correlation coefficient was used. Scattergram data and a Bland-Altman diagram were used to evaluate the dispersion and differences between the results obtained using the FF and direct assay, and $P$ values <

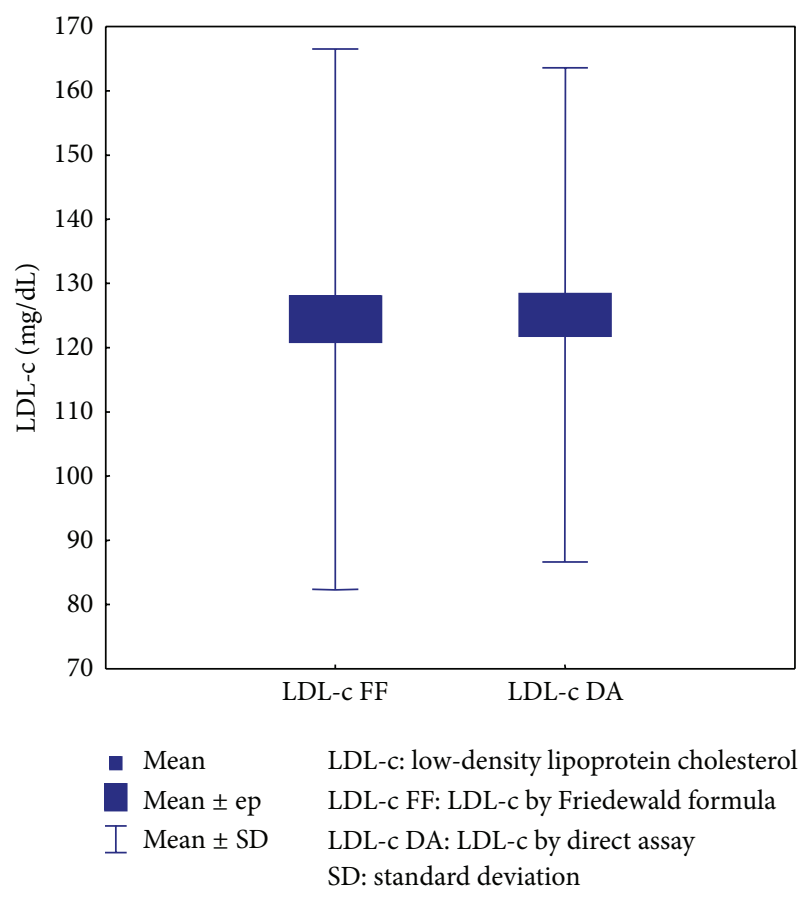

FIGURE 1: Relationship between the LDL-c values using the FF and direct dosage.

0.05 were considered to be statistically significant. Data were analyzed with the software Statistica v.8.0.

\section{Results}

The sample size comprised 135 individuals. Using the FF, the statistical analysis of LDL-c showed a mean value of $124.4 \mathrm{mg} / \mathrm{dL}(\mathrm{SD}=42.1 \mathrm{mg} / \mathrm{dL})$; by direct assay, the mean value was $125.1 \mathrm{mg} / \mathrm{dL}(\mathrm{SD}=38.5 \mathrm{mg} / \mathrm{dL})$. The difference between the FF and direct measurement showed strong correlation between both methods because the mean difference was $-0.7 \mathrm{mg} / \mathrm{dL}$, as shown in Figure 1 .

We subdivided the patients based on their TG values to analyze whether the different methods used produced different values for this lipid. In the group of patients with $\mathrm{TG} \leq 150 \mathrm{mg} / \mathrm{dL}(n=50)$, no significant difference between the methods ( $P=0.881$ ) was observed; in the patient group with TG $>150 \mathrm{mg} / \mathrm{dL}$, there was also no significant difference between the two methods $(P=0.618)$, as shown in Figure 2 .

To assess the degree of association between the methods, we estimated the correlation coefficient between them, which equaled 0.89 , with statistical significance $(P<0.001)$. Thus, based on the results of the statistical tests, we believe that there is no significant difference between the assessment of LDL-C using the FF and by direct measurement, as shown in Figure 3.

As shown in Figure 4, it is possible to conclude that, in general, the FF underestimates the value of LDL-c compared to direct measurement. Moreover, the average difference between these methods appears to be more pronounced when the LDL-c is lower (by direct measurement): when LDL-c 


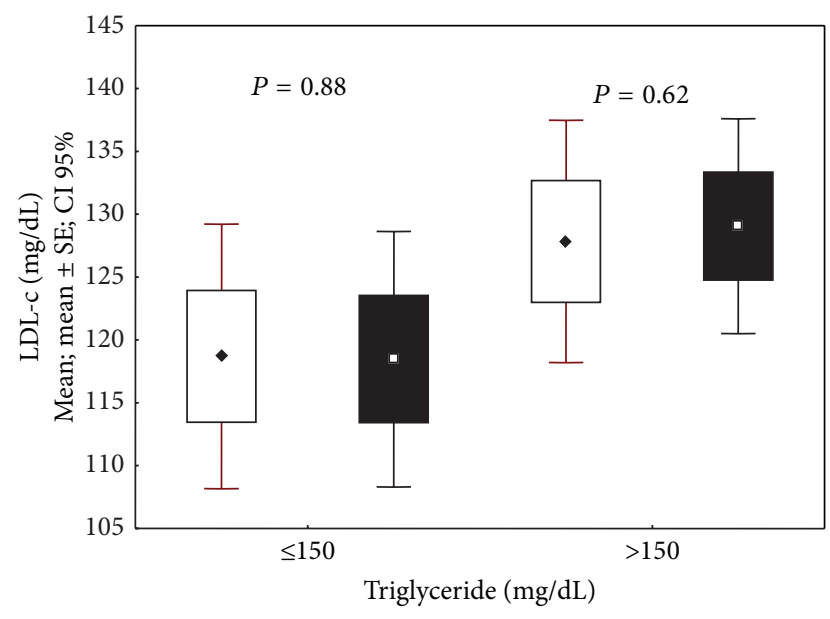

$\begin{array}{ll}\text { Friedewald formula } & \text { SE: standard error } \\ \text { a Direct assay } & \text { CI } 95 \% \text { : } 95 \% \text { confidence interval }\end{array}$

FIGURE 2: Evaluation of LDL-c values by triglyceride level with the $\mathrm{FF}$ and direct assay.

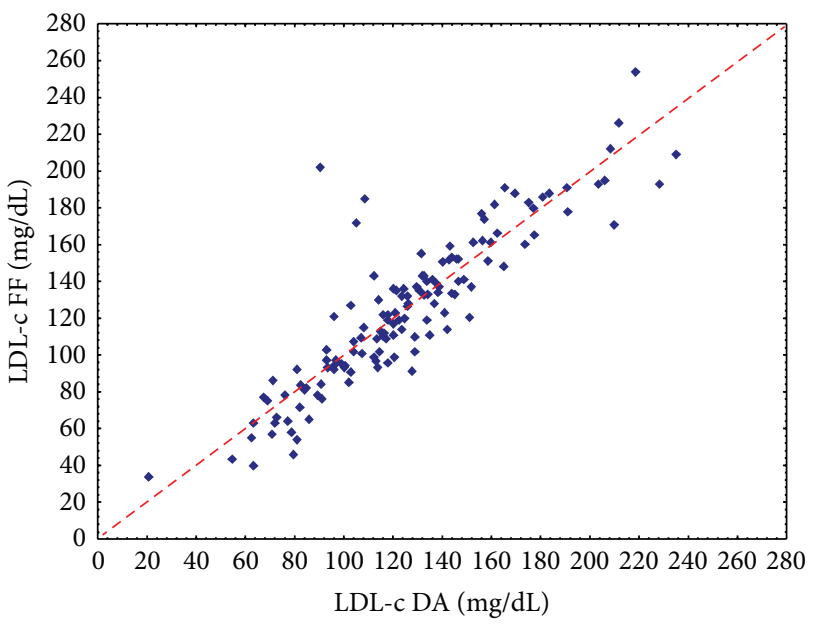

LDL-c: low-density lipoprotein cholesterol

LDL-c FF: LDL-c by the Friedewald formula

LDL-c DA: LDL-c by direct assay

FIGURE 3: Scattergram data between LDL-c values by Friedewald formula and by direct assay.

$\leq 121 \mathrm{mg} / \mathrm{dL}$, the mean difference was $0.26 \mathrm{mg} / \mathrm{dL}$, and for LDL-c $>121 \mathrm{mg} / \mathrm{dL}$, the mean difference was $-1.62 \mathrm{mg} / \mathrm{dL}$. However, despite being approximately six times greater when the absolute difference in LDL-c $>121 \mathrm{mg} / \mathrm{dL}$, this result is still too small and is clinically insignificant.

A minority of patients $(n=9)$ demonstrated an absolute difference $>30 \mathrm{mg} / \mathrm{dL}$ between both methods, which could be clinically significant, as shown in Figure 4 . Eight of these patients had TG $>150 \mathrm{mg} / \mathrm{dL}$, but just one patient had a level $>300 \mathrm{mg} / \mathrm{dL}$. Considering that the mean value of TG in all patients with TG $>150 \mathrm{mg} / \mathrm{dL}$ in this study was $219.1 \mathrm{mg} / \mathrm{dL}$, we concluded that patients with important differences in

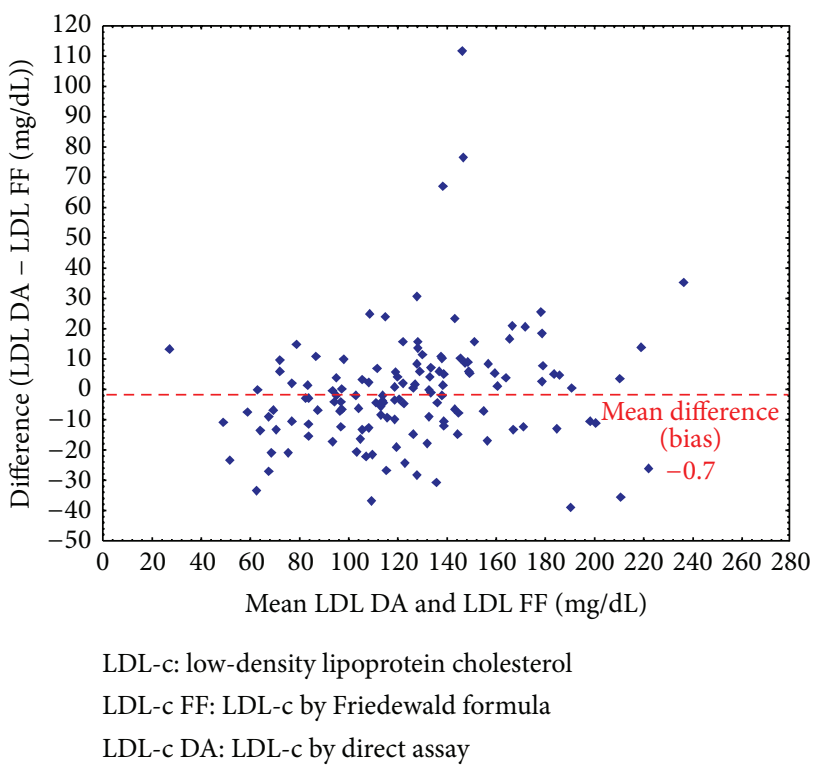

FIGURE 4: A Bland-Altman diagram correlating the absolute difference between the two methods and their means.

their LDL-c values (using the FF and direct assay) were not clustered in higher triglyceride level group.

The relative difference between the calculated value of LDL-c using the FF and the direct measurement was that, on average, the value of the FF is $0.28 \%$ lower than the direct measurement.

\section{Discussion}

As the relationship between serum LDL-c and cardiovascular disease is well established, reliable methods of measuring this lipid are needed both to classify it and to treat our patients. However, recently, many studies have demonstrated limitations to the most widely used method for serum LDL-c estimation, the FF.

Despite the classical indication for direct measurement of LDL-c as TG $>400 \mathrm{mg} / \mathrm{dL}$, some studies have indicated that, for lower TG values, the FF is not as reliable. From $180 \mathrm{mg} / \mathrm{dL}$, the FF already shows significant differences (overestimating LDL-c values) when compared to direct measurement methods $[17,18]$. Similar results were shown by Charuruks and Milintagas [19], who indicated the direct measurement of LDL-c when TG $\geq 200 \mathrm{mg} / \mathrm{dL}$ because they found that the direct method was more precise and accurate than FF, even for TG levels between 200 and $399 \mathrm{mg} / \mathrm{dL}$. One Brazilian study showed a similar conclusion for FF use [20]. Nevertheless, these findings do not align with those of our study, in which the LDL-c value was estimated with precision by the $\mathrm{FF}$ for any value of TG $<400 \mathrm{mg} / \mathrm{dL}$.

Some studies have shown that FF can also display discrepancies in low TG values [17, 21,22]. When TG value was $<70 \mathrm{mg} / \mathrm{dL}$, the estimated LDL-c using the FF showed slightly lower values than that using the direct method [17]. Contradictory results have been demonstrated in other studies, in which serum LDL-c using the FF was higher than 
the homogeneous assay for TG $<100$ or $200 \mathrm{mg} / \mathrm{dL}[21,22]$. In the present study, LDL-c values using the FF were virtually identical to the values by direct assay, particularly when $\mathrm{TG} \leq$ $150 \mathrm{mg} / \mathrm{dL}$ (mean difference between LDL-c using the FF and direct measurement $=0.2$ ).

New studies are demonstrating the limited efficacy of FF in diabetic patients. Diabetes is the epitome of MS; thus, many of these studies have affirmed that this estimation is not as accurate for this syndrome as previously believed $[6,18,23]$. In diabetic patients, with or without insulin use, the FF underestimates, on average, $8 \%$ serum LDL-c, but it can underestimate more than $10 \%$ in patients with TG levels between 200 and $400 \mathrm{mg} / \mathrm{dL}$ [18].

We found only one study in the literature that correlated the efficacy of FF and a direct assay specifically in patients with MS. The authors found that the direct measurement method is more accurate than the FF in these patients; these results represent the limitations of this indirect method. However, the authors also noted that even direct assays have limitations in identifying small and dense LDL-c, which is abundant in these patients [23]. In the current study, all patients with MS and TG $<400 \mathrm{mg} / \mathrm{dL}$ demonstrated reliable LDL-c value estimates using the FF.

\section{Conclusion}

In conclusion, $\mathrm{FF}$ is a reliable method to estimate serum LDL$\mathrm{c}$ in patients with MS.

\section{Conflict of Interests}

The authors have declared no conflict of interests regarding the publication of this paper.

\section{Acknowledgments}

The study was funded by a scholarship provided by Fundação Araucária through an undergraduate research project at Pontifícia Universidade Católica do Paraná. The study was approved by Comitê de Ética em Pesquisa da Pontifícia Universidade Católica do Paraná.

\section{References}

[1] J. Jeppesen, T. W. Hansen, S. Rasmussen, H. Ibsen, and C. Torp-Pedersen, "Metabolic syndrome, low-density lipoprotein cholesterol, and risk of cardiovascular disease: a populationbased study," Atherosclerosis, vol. 189, no. 2, pp. 369-374, 2006.

[2] D. Q. F. Penalva, "Síndrome metabólica: diagnóstico e tratamento," Revista de Medicina, vol. 87, no. 4, pp. 245-250, 2008.

[3] Sociedade Brasileira de Hipertensão, Sociedade Brasileira de Cardiologia, Sociedade Brasileira de Endocrinologia e Metabologia, Sociedade Brasileira de Diabetes, and Associação Brasileira para Estudos da Obesidade, "I Diretriz Brasileira de Diagnóstico e Tratamento da Síndrome Metabólica," Arquivos Brasileiros de Cardiologia, vol. 84, supplement 1, pp. 3-28, 2005.

[4] R. L. Luna, "Síndrome metabólica," Arquivos Brasileiros de Cardiologia, vol. 88, no. 5, pp. 124-126, 2007.
[5] H. P. Himsworth, "The mechanism of diabetes mellitus," The Lancet, vol. 234, no. 6046, pp. 118-122, 1939.

[6] J. I. Cleeman, "Executive summary of the third report of the National Cholesterol Education Program (NCEP) expert panel on detection, evaluation, and treatment of high blood cholesterol in adults (adult treatment panel III)," Journal of the American Medical Association, vol. 285, no. 19, pp. 2486-2497, 2001.

[7] A. C. Sposito, B. Caramelli, F. H. Fonseca, M. C. Bertolami, and Departamento de Aterosclerose da Sociedade Brasileira de Cardiologia, "IV Diretriz brasileira sobre dislipidemias e prevenção da aterosclerose. Arquivos Brasileiros de Cardiologia," Arquivos Brasileiros de Cardiologia, vol. 88, supplement 1, 2007.

[8] A. F. A. Siqueira, D. S. P. Abdalla, and S. R. G. Ferreira, "LDL: da síndrome metabólica à instabilização da placa aterosclerótica," Arquivos Brasileiros de Endocrinologia and Metabologia, vol. 50, no. 2, pp. 334-343, 2006.

[9] M. Nauck, G. R. Warnick, and N. Rifai, "Methods for measurement of LDL-cholesterol: a critical assessment of direct measurement by homogeneous assays versus calculation," Clinical Chemistry, vol. 48, no. 2, pp. 236-254, 2002.

[10] S. Kathiresan, J. D. Otvos, L. M. Sullivan et al., "Increased small low-density lipoprotein particle number: a prominent feature of the metabolic syndrome in the Framingham Heart Study," Circulation, vol. 113, no. 1, pp. 20-29, 2006.

[11] A. J. Tremblay, H. Morrissette, J.-M. Gagné, J. Bergeron, C. Gagné, and P. Couture, "Validation of the Friedewald formula for the determination of low-density lipoprotein cholesterol compared with $\beta$-quantification in a large population," Clinical Biochemistry, vol. 37, no. 9, pp. 785-790, 2004.

[12] S. M. Grundy, J. I. Cleeman, S. R. Daniels et al., "Diagnosis and management of the metabolic syndrome: an American Heart Association/National Heart, Lung, and Blood Institute scientific statement," Circulation, vol. 112, no. 17, pp. 2735-2752, 2005.

[13] W. T. Friedewald, R. I. Levy, and D. S. Fredrickson, "Estimation of the concentration of low-density lipoprotein cholesterol in plasma, without use of the preparative ultracentrifuge," Clinical Chemistry, vol. 18, no. 6, pp. 499-502, 1972.

[14] G. Schectman, M. Patsches, and E. A. Sasse, "Variability in cholesterol measurements: comparison of calculated and direct LDL cholesterol determinations," Clinical Chemistry, vol. 42, no. 5, pp. 732-737, 1996.

[15] I. Türkalp, Z. Cil, and D. Ozkazanç, "Analytical performance of a direct assay for LDL-cholesterol: a comparative assessment versus Friedewald's formula," Anadolu Kardiyoloji Dergisi, vol. 5, pp. 13-17, 2005.

[16] S. Mora, N. Rifai, J. E. Buring, and P. M. Ridker, "Comparison of LDL cholesterol concentrations by Friedewald calculation and direct measurement in relation to cardiovascular events in 27 331 women," Clinical Chemistry, vol. 55, no. 5, pp. 888-894, 2009.

[17] J. P. J. Piva and T. R. L. Fernandes, "Comparação analítica de valores de LDL-colesterol utilizando a dosagem direta e o cálculo pela fórmula de Friedewald," Revista Brasileira de Análises Clínicas, vol. 40, no. 4, pp. 279-283, 2008.

[18] S. Hirany, D. Li, and I. Jialal, "A more valid measurement of low-density lipoprotein cholesterol in diabetic patients," The American Journal of Medicine, vol. 102, no. 1, pp. 48-53, 1997.

[19] N. Charuruks and A. Milintagas, "Evaluation of calculated lowdensity lipoprotein against a direct assay," Journal of the Medical Association of Thailand, vol. 88, supplement 4, pp. S274-S279, 2005. 
[20] C. M. M. de Cordova, C. R. Schneider, I. D. Juttel, and M. M. de Cordova, "Avaliação da dosagem direta do colesterol-LDL em amostras de sangue de 10664 pacientes em comparação com o uso da fórmula de Friedewald," Arquivos Brasileiros de Cardiologia, vol. 83, no. 6, pp. 476-481, 2004.

[21] S. Sahu, R. Chawla, and B. Uppal, "Comparison of two methods of estimation of low density lipoprotein cholesterol, the direct versus Friedewald estimation," Indian Journal of Clinical Biochemistry, vol. 20, no. 2, pp. 54-61, 2005.

[22] S.-A. Ahmadi, M.-A. Boroumand, K. Gohari-Moghaddam, P. Tajik, and S.-M. Dibaj, "The impact of low serum triglyceride on LDL-cholesterol estimation," Archives of Iranian Medicine, vol. 11, no. 3, pp. 318-321, 2008.

[23] I. Gazi, V. Tsimihodimos, T. D. Filippatos et al., "LDL cholesterol estimation in patients with the metabolic syndrome," Lipids in Health and Disease, vol. 5, article 8, 2006. 


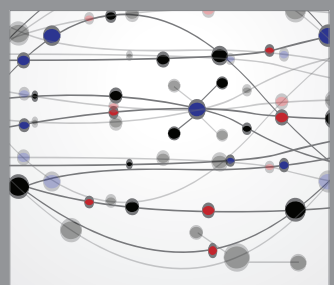

The Scientific World Journal
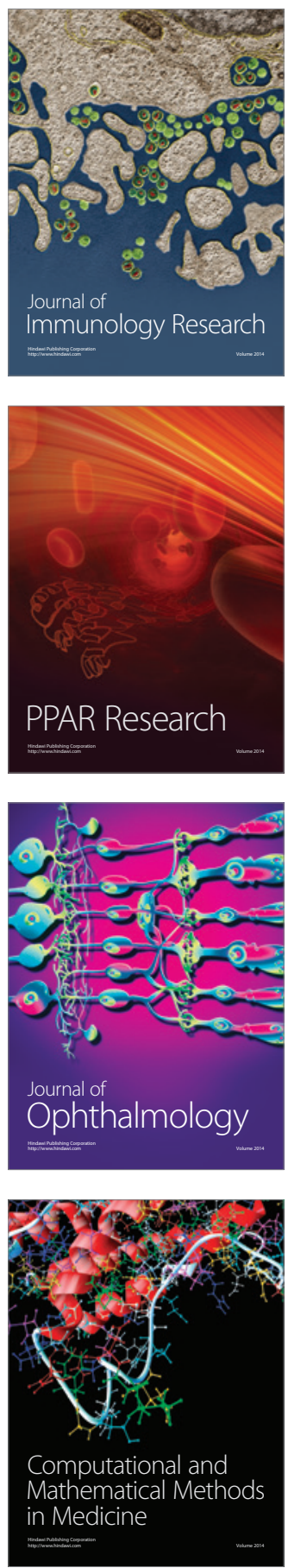

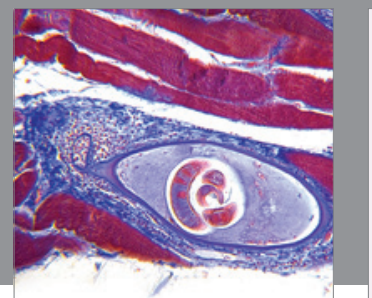

Gastroenterology

Research and Practice
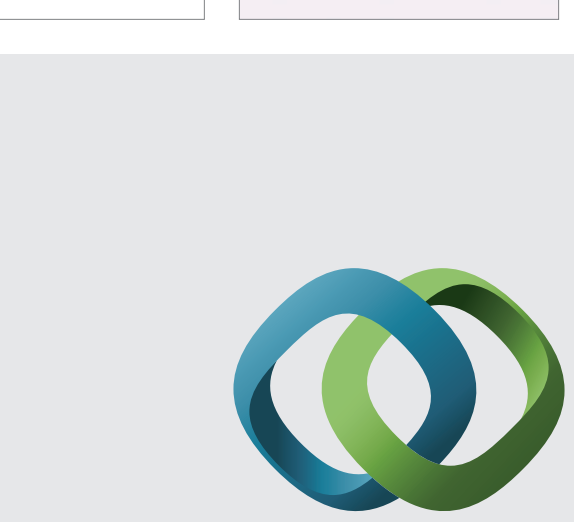

\section{Hindawi}

Submit your manuscripts at

http://www.hindawi.com
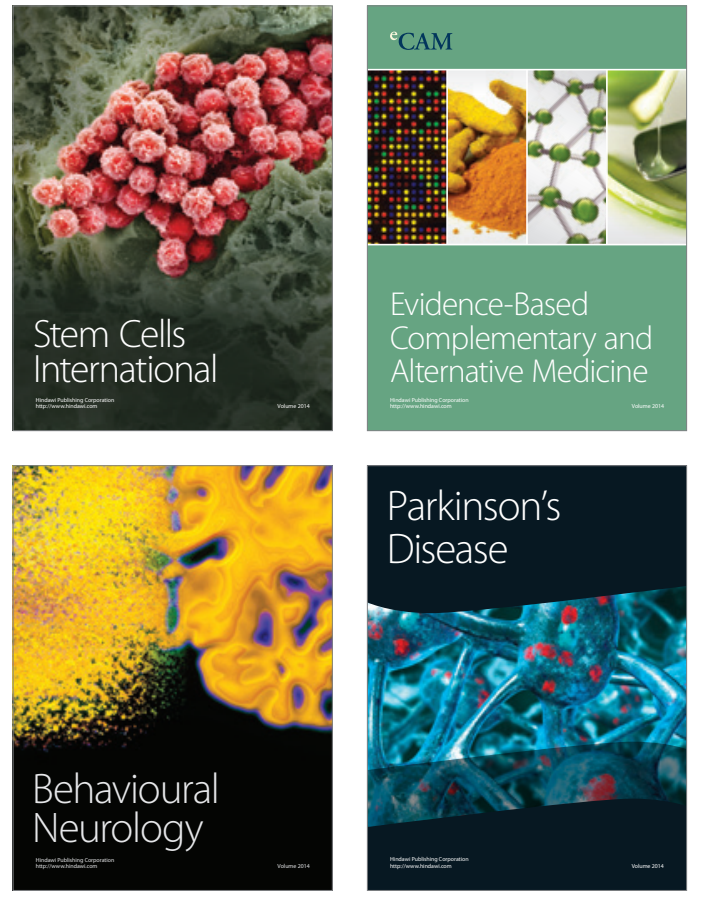
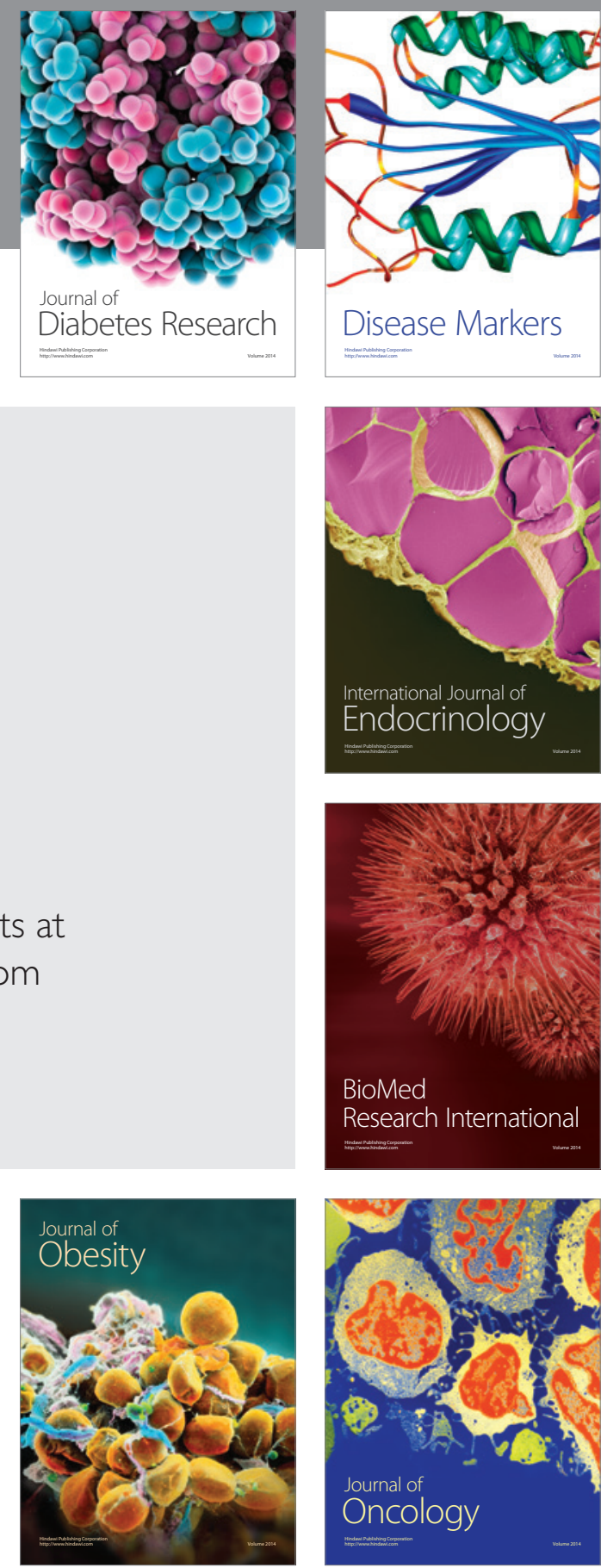

Disease Markers
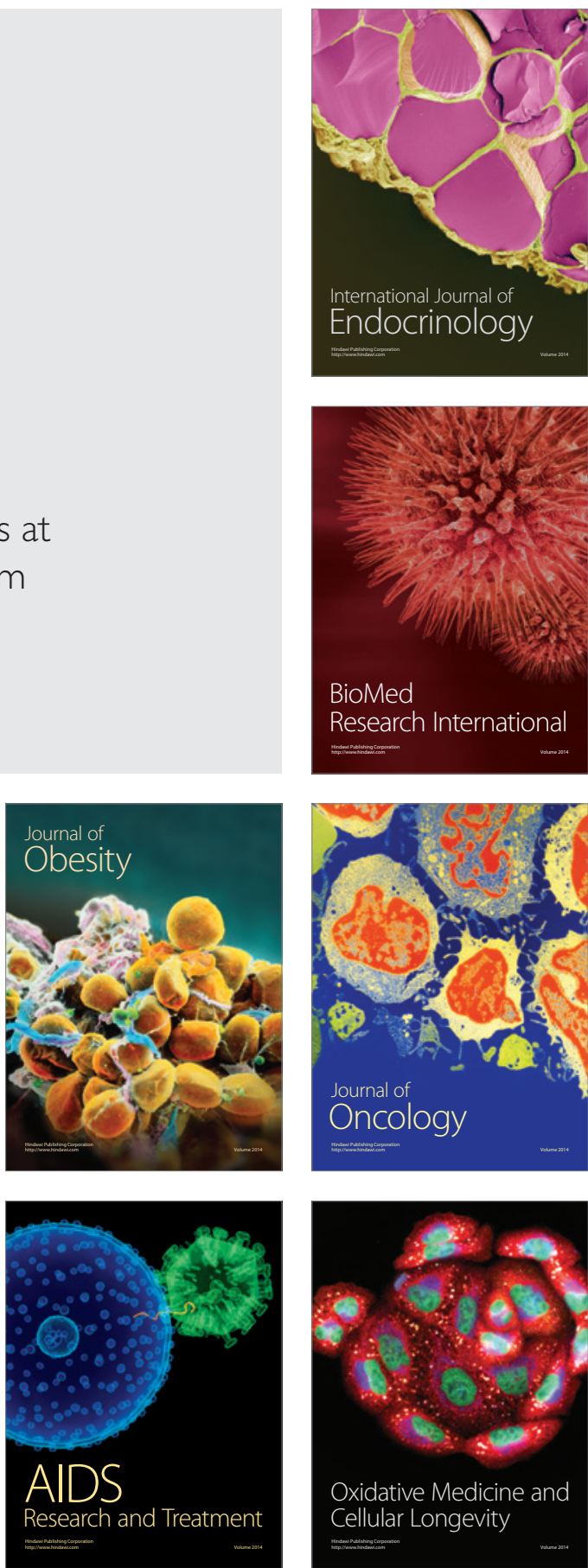